УДК 656.071.4

DOI 10.47049/2226-1893-2021-1-81-98

\title{
ЗАРОДЖЕННЯ І РОЗВИТОК ВНУТРІШНЬОПОРТОВОГО ОПЕРАТИВНОГО УПРАВЛІННЯ
}

\author{
О.В. Кириллова \\ д.т.н., професор, \\ завідувач кафедри «Експлуатація портів і технологія вантажних робіт» \\ О.Р. Магамадов \\ к.т.н., професор кафедри «Експлуатація портів і технологія вантажних робіт» \\ Б.В. Шурін \\ ст. викладач кафедри «Експлуатація портів і технологія вантажних робіт» \\ Одеський національний морський університет, Україна, Одеса
}

\section{Без ретроспективи немас перспективи. \\ В.С.Тімонов}

\begin{abstract}
Анотація. Викладено результати дослідження еволюиії внутрішньопортового оперативного управління (BОУ) як прикладної науки з виділенням донаукової $і$ наукової стадій і етапів ї̈ розвитку та характеристикою досягнутих на кожному етапі наукових результатів. Показано, що початок донаукової стадії формування ВОУ слід пов'язувати з виникненням професійної діяльності по організаиії завантаженнярозвантаження суден біля необладнаного морського узбережжя, а іï закінченням вважати затвердження концепиї «експлуатаційної справи в портах». Цей термін запропоновано розглядати і в якості початкової віхи наукової стадї розвитку ВОУ на етапах зародження, становлення, створення методології $i$ подальшого вдосконалення аж до сучасного стану. Встановлено, щуо на науковій стадї прогресування ВОУ принципово важливе значення мали: на етапі зародження - обтрунтування необхідності впровадження планування в оперативне управління портовим виробництвом; на етапі становлення - визнання корисності комплексного розвитку практики і теорії внутрішньопортового управління; на етапі створення методологї - початок розробки теоретичних положень і методичного інструментарію ВОУ в застосуванні до процесу обробки суден; на етапі оптимізації та автоматизаиії ВОУ інтенсивне збагачення методології оперативного управління обробкою суден принципами, підходами і методами народжених науково-технічною революцією наук і розгортання на иій основі робіт зі створення автоматизованих систем управління роботою портів.

Ключові слова: управління портом, наука, зародження, становлення, розвиток, методологія, оптимізачія і автоматизація управління.
\end{abstract}

(С) Кириллова О.В., Магамадов О.Р., Шурін Б.В., 2021 
ВІСНИК

ОДЕСЬКОГО НАЦІОНАЛЬНОГО

МОРСЬКОГО УНІВЕРСИТЕТУ

№ 1 (64), 2021
HERALD

OF THE ODESSA NATIONAL

MARITIME UNIVERSITY № 1 (64), 2021

\section{УДК 656.071.4}

DOI 10.47049/2226-1893-2021-1-81-98

\section{ЗАРОЖДЕНИЕ И РАЗВИТИЕ ВНУТРИПОРТОВОГО ОПЕРАТИВНОГО УПРАВЛЕНИЯ}

Е.В. Кириллова

д.т.н., профессор,

заведующая кафедрой «Эксплуатация портов и технология грузовых работ»

А.P. Магамадов

к.т.н., профессор кафедры «Эксплуатация портов и технология грузовых работ»

Б.В. Шурин

ст. преподаватель кафедры «Эксплуатация портов и технология грузовых работ»

Одесский национальный морской университет, Украина, Одесса

Без ретроспективы

нет ретроспективы.

В.Е. Тимонов

Аннотация. Изложены итоги исследования эволючии внутрипортового оперативного управления (ВОУ) как прикладной науки с выделением донаучной и научной стадий и этапов ее развития и характеристикой достигнутых на каждом этапе научных результатов. Показано, что начало донаучной стадии формирования ВОУ следует связывать c возникновением профессиональной деятельности по организации загрузки-разгрузки судов у необорудованных морских побережий, а ее окончанием считать утверждение концепции «эксплуатационного дела в портах». Эту временную гранииу предложено рассматривать и в качестве начальной вехи научной стадии развития ВОУ на этапах зарождения, становления, создания методологии и дальнейшего совершенствования вплоть до современного состояния. Установлено, что на научной стадии прогрессирования ВОУ принципиально важное значение имели: на этапе зарождения - обоснование необходимости внедрения планового начала в оперативное управление портовым производством; на этапе становления - признание полезности комплексного развития практики и теории внутрипортового управления; на этапе создания методологии - начало разработки теоретических положений и методического инструментария ВОУ в приложении к процессу обработки судов; на этапе оптимизации и автоматизации ВОУ - интенсивное обогащение методологии оперативного управления обработкой судов принципами, подходами и методами рожденных научно-технической револючией наук и развертывание на этой основе работ по созданию автоматизированных систем управления работой портов.

Ключевые слова: управление портом, наука, зарождение, становление, развитие, методология, оптимизация и автоматизация управления. 
UDC 656.071.4

DOI 10.47049/2226-1893-2021-1-81-98

\title{
THE ORIGIN AND DEVELOPMENT OF INTRA-PORT OPERATIONAL MANAGEMENT
}

\section{E.V. Kirillova}

Doctor of Technical Sciences, Professor, Head of the Department of «Port Operation and Cargo Technology» A.R. Magamadov

Ph.D., Professor of the Department of «Port Operation and Cargo Technology» B.V. Shoorin Lecturer at the Department of «Port Operation and Cargo Technology» Odessa National Maritime University, Ukraine, Odessa

Without retrospective no retrospective. V.E. Timonov

\begin{abstract}
The results of the study of the evolution of in-port operational management (POM) as an applied science are presented, highlighting the pre-scientific and scientific stages and stages of its development and characterizing the scientific results achieved at each stage. It is shown that the beginning of the pre-scientific stage of POM formation should be associated with the emergence of professional activity in organizing loading and unloading of ships near unequipped sea coasts, and its end should be considered the approval of the concept of "operational business in ports». It is proposed to consider this time limit as an initial milestone in the scientific stage of POM development at the stages of origin, formation, creation of a methodology and further improvement up to the current state. It has been established that at the scientific stage of POM progression, the following were of fundamental importance: at the inception stage - substantiation of the need to introduce the planned principle into the operational management of port production; at the stage of formation - recognition of the usefulness of the integrated development of the practice and theory of in-port management; at the stage of creating a methodology - the beginning of the development of theoretical provisions and methodological tools for POM in the application to the process of handling ships; at the stage of optimization and automation of POM intensive enrichment of the methodology for operational management of ship handling with the principles, approaches and methods born of the scientific and technological revolution of sciences and the deployment on this basis of work on the creation of automated control systems for port operations.

It is shown that the key provisions of the POM system optimization are: the concept of adaptive control as a combination of program (planning), tracking (accounting, control, analysis) and stabilizing (regulation) control; a situational planning mechanism in conjunction with rolling planning; correct and at the same time useful for practice economic and mathematical models of
\end{abstract}


problems of distribution of handling operation's resources between ships and the use of resources when handling ships; a methodology for the simultaneous compilation of dislocation schedules of ships, schedules for loading and discharging ships and shift-daily plans in terms of ship operations. The analysis of the experience in the development of automated port control systems (ACS «PORT» in the 1970s, "Digital dispatcher office» in 2017) was carried out.

Keywords: port management, science, origin, formation, development, methodology, optimization and automatization of management.

Вступ. Як відомо, наукова творчість грунтується на методологічному арсеналі теорії пізнання, обов'язковою складовою якого $є$ істини, що постулюються, - аксіоми, правила, традиції і т.п. Одна з таких істин полягає в твердженні, що поступ у розвитку будь-якої науки є результативним за умови зведення іiі майбутнього на фундаменті минулого. Усвідомлене слідування вказаному постулату дозволяє, зокрема, передбачати отримання «нових» наукових знань в процесі переосмислення раніше проведених досліджень та здобутих, але «добре забутих» результатів.

Саме цією обставиною обумовлюється актуальність розглянутого питання, щодо зародження і розвитку внутрішньопортового оперативного управління (ВОУ) як прикладної науки.

Постановка і аналіз досліджуваної проблеми. Відзначимо відразу, що в транспортній літературі відсутні публікації щодо цілісного висвітлення ВОУ як науки, що охоплює ключові питання теорії i практики забезпечення ефективного функціонування портів на етапі оперативного (в межах місяця) управління. Існує тільки два джерела $[1 ; 2]$, в яких наведені принципово важливі дані про зародження i розвиток ВОУ протягом п'ятдесяти років (з 1920 по 1970 рр.). Проте допущена неточність 3 визначенням часу зародження обговорюваної науки, про що докладніше буде сказано нижче 3 використанням інформації з [3]. В інших джерелах, включаючи дисертаційні дослідження [4-7], згадуються лише окремі факти про становлення теоретичних основ ВОУ і створення відповідного методичного інструментарію цієї науки протягом другої половини XX століття.

Виходячи 3 вищевикладеного, в даній роботі ставиться мета заповнити зазначений пробіл. При цьому приймаються такі завдання дослідження:

- охарактеризувати еволюцію ВОУ від зародження до сучасного стану із зазначенням часових меж її стадій і етапів;

- викласти концепцію системної оптимізації ВОУ в частині, яка пов'язана з управлінням процесом обробки суден;

- визначити найбільш актуальний і одночасно реально досяжний напрямок подальшого розвитку ВОУ. 
При цьому відзначимо, що під системною оптимізацією ВОУ тут розуміється забезпечення максимально можливої вигоди для портів від обслуговування суден у постановці - від швартування до причалів і до відшвартування від причалів.

Основний матеріал дослідження. ВОУ відноситься до категорії прикладних наук, в історії формування яких прийнято виділяти дві стадії:

- донаукову, коли відбувається накопичення практичного досвіду, a спостережувані об'єкти (явища, процеси, системи і т.п.) пізнаються шляхом їх емпіричного опису;

- наукову, коли для отримання об'єктивних суджень про природу i властивості спостережуваних об'єктів використовуються наукові знання.

У більшості випадків перша із зазначених стадій охоплює тривалий (в кілька століть і навіть тисячоліть) період часу і відрізняється повільною зміною раніше сформованих уявлень щодо об'єктів, які розглядаються. Для другої стадії характерно перманентний (найчастіше протягом декількох десятиліть) розвиток наук від їх зародження до сучасного стану.

У разі ВОУ початок донаукової стадії цієї науки логічно пов'язувати 3 фактом організації завантаження першого в світі судна, що хронологічно сталося ще задовго до появи морських портів, приблизно в XII-XI століттях до нашої ери.

В ті часи торгові судна прибували за вантажами і з вантажами до необладнаного узбережжя, ставали на якір і оброблялися за варіантами відповідно берег-водний простір-судно і у зворотному напрямку. При цьому вантажно-розвантажувальні операції виконувалися з використанням найпростіших плавучих засобів і суднових команд в якості робочої сили.

Згодом для виконання завантаження-розвантаження суден їх капітани почали залучати на платній основі жителів прибережних поселень. Так з'явилися професійні вантажники, яких з повною на те підставою можна вважати прабатьками сучасних портових робітниківдокерів.

Народження професійних вантажників послужило поштовхом до виникнення спеціалізованих підприємств, призначення яких полягало в організації і здійсненні вантажної обробки суден. Так з'явилися стивідорні компанії, яким випало стати спочатку своєрідною моделлю майбутніх морських портів, а потім автономними суб'єктами виробничої діяльності в портах (портовими операторами).

Донаукова стадія ВОУ прийшла до свого завершення в першому двадцятиріччі XX століття. Ї̈̈ сукупний підсумок полягав у визначенні опитним шляхом основних правил організації обробки суден, способів і прийомів виконання вантажно-розвантажувальних операцій, а також 
раціональних підходів до керівництва завантаженням-розвантаженням суден.

Паралельно з цим складався зміст портової діяльності, яку з часом почали іменувати «експлуатаційною справою в портах» [8].

У ці роки, як відзначає талановитий спеціаліст у галузі управління морським флотом I.А. Сергєєв, у практиці експлуатації водного транспорту переважали методи, що формувалися на дотик. Цю ситуацію I.А. Сергєєв образно порівнював 3 «...незайманим полем, ще тільки чекаючим своїх плугатарів, яким доведеться починати дослідницьку роботу буквально з розчистки цілини» (цитується у перекладі на українську мову по $[2$, с.6]).

У таких обставинах розпочиналася наукова стадія розвитку ВОУ. Вона включала в себе ряд відносно відокремлених, але пересічних в часі етапів, кожен з яких охоплює певне коло взаємопов'язаних питань $\mathrm{i}$ практичного досвіду щодо портової діяльності з метою їх вирішення. При цьому часові межі етапів фіксуються по роках опублікування принципово важливих результатів досліджень.

Перший етап (1890-1934 роки) - етап зародження ВОУ - характеризується накопиченням теоретичних знань і практичного досвіду щодо портової діяльності 3 метою їх узагальнення та впровадження на цій основі раціональної системи управління портами. При цьому, ще в кінці XIX століття у якості вельми важливого завдання ВОУ видатний інженер і вчений водного транспорту В.С. Тімонов визначав забезпечення портової діяльності професійно підготовленими експлуатаційниками. Так, у доповіді на VI з’їзді російських діячів по водним шляхам [3] він звертав увагу на те, що до середини XIX століття торговельні порти являлися більш-менш безпечними сховищами для морських суден. У такій ситуації, на погляд вченого, для спостереження за порядком в порту була потрібна особа, яка тільки володіла спритністю і здоровим глуздом задля того, щоб керувати портовими робітниками, які виконували операції по вантажній обробці суден. Проте, через півстоліття, пояснював В.С. Тімонов, ситуація кардинально змінилася: порти перетворились у приморські транспортні вузли, які зв'язали у суцільну транспортну мережу сухопутні внутрішні та морські водні шляхи. У портах з'явилися постійні вантажні фронти 3 відповідним технічним оснащенням і контингентом фахівцівтехніків. У підсумку стало вочевидь, вважав вчений, що для ефективного управління діяльністю торговельного порту стала потрібна особа не тільки зі здоровим глуздом, розпорядна та спритна, але й здатна відповісти всім технічним запитам, які висуваються у цій справі.

На початку 1920-х років також встановлено, що основою управління роботою порту повинен бути плановий підхід. Як стверджував, 3 цього приводу один з відомих фахівців в області наукової організації праці на транспорті В.Д. Єщенко, для забезпечення раціонального управ- 
ління будь-яким підприємством потрібно попередньо скласти план, який повинен передбачати найближче майбутнє гранично чітко, а більш віддалене майбутнє - досить ясно [9].

Другий етап (1928-1940 роки) - етап становлення ВОУ характеризується реалізацією концепції комплексного розвитку практики i теорії внутрішньопортового управління на всіх часових інтервалах. У цей період висунуто багато плідних ідей, які об'єднали накопичені наукові знання і практичні прийоми, а також багато в чому визначили подальший розквіт творчої діяльності у сфері управління роботою портів у частині реалізації функції оперативного планування.

Найважливішим результатом цього етапу, як показано в [10], є визначення того факту, що виграш від теоретичного висвітлення експлуатаційної діяльності полягає у можливості планомірно і швидко переглядати способи виконання вантажоперевалювальних робіт у відповідності 3 умовами роботи, які змінилися [10]. Саме, в ці роки набула визнання необхідність переходу від окомірних, інтуїтивних способів управління транспортним процесом до методів, заснованих на строго науковій і технічній базі. Виступаючи з цього приводу на сторінках журналу «Водний транспорт», відомий вчений В.В. Звонков, підкреслював, що нові методи можуть забезпечувати найкращі результати в тому випадку, якщо поряд 3 виробленням принципових установок будуть створені конкретні керівництва для повсякденного життя. В умовах портів таким керівництвом міг бути план, що охоплює відносно невеликий інтервал часу, тобто оперативний план.

Впровадження оперативного планування (спочатку у формі «Добового журналу роботи суден в порту», а потім у формі «Зміннодобового плану роботи порту»), а також диспетчерської звітності та диспетчерського режиму керівництва додало ВОУ риси організаційно- i структурно сформованої системи [11], процес створення якої завершився в середини 1930-х років, коли функції оперативного планування, диспетчерського керівництва і диспетчерської звітності були передані одному органу, яким в портах стала служба експлуатації [12-14].

3 затвердженням у 1936 році «Керівництва по низовому плануванню перевантажувальних робіт на морському транспорті» [15] визначився загальний порядок організації роботи портів. Цей документ містив також методичні матеріали 3 організації завантаження-розвантаження суден, які проте не мали необхідного теоретичного обгрунтування внаслідок того, що в цей період теорія експлуатації морського транспорту все ще перебувала в стані становлення. Проте згаданий документ дозволив досить чітко визначити область першочергових досліджень і активізувати роботу зі створення основ наукового забезпечення ВОУ.

Важливо підкреслити, що у той період відносно питання про режим оперативного планування роботи порту і особливо обробки суден 
у той період, єдиної точки зору не існувало. Поряд з твердженням про те, що для морських портів найбільш доцільним є змінно-добове планування [16], висловлювалися і інші міркування. Так у роботах [17-18] у відповідності з [9] пропонувалося складати плани не тільки на чергову добу, але і на більш тривалі періоди для забезпечення передбачення розвитку виробничої ситуації в порту і створення на поточному етапі умов, які дозволяють успішно виконувати програму робіт на наступних етапах.

Третій етап (1936-1966 роки) - етап створення методології ВОУ протікав в складній обстановці. Розгорнуту в його перше п'ятиріччя науково-дослідницьку роботу перервала друга світова війна. Роботи у цьому напрямку відновилися лише на початку 1950 -х років, напередодні науково-технічної революції. І все ж, незважаючи на перехідний характер етапу, його результати можна розглядати як початок розробки теоретичних положень і методичного арсеналу ВОУ. Отримані в цей період результати знайшли відображення в науковій [19-21], виробничотехнічній [22-23] і навчальній літературі [24-26].

На етапі розвитку ВОУ, що характеризується, затвердилася точка зору, яка відзначала, що ефективне управління процесом обробки суден може бути забезпечено шляхом розробки наступних видів планів:

- дислокаційного (декадного, тижневого, п'ятиденного) графіку обробки суден, які вже прибули в порт і знаходяться на підході до нього;

- графіків завантаження-розвантаження окремих суден;

- змінно-добових планів роботи порту (розділ «Суднові роботи»).

Підкреслимо, що ця трьохланкова система планів залишається актуальною до теперішнього часу в силу своєї теоретичної переконливості і практичної можливості бути реалізованою при умові забезпечення узгодження показників усіх видів планів, як це показано в $[1 ; 2]$.

Ще один принципово важливий результат методологічного характеру, здобутий на початку розглянутого етапу, стосувався обгрунтування правомірності постановки двох взаємопов'язаних завдань - про розподіл портових перевантажувальних ресурсів між прийнятими до обробки суднами і про використання ресурсів на суднах під час виконання вантажно-розвантажувальних операцій. Ця ідея всебічно обгрунтована в $[1 ; 2]$ і до сих пір зберігає актуальність.

Доречно відзначити, що у більшості ранніх публікацій, які присвячені темі розподілу перевантажувальних ресурсів між суднами, центральне місце займають різноманітні аспекти питання «вузького фронту» в організації обробки суден. Так, В.Г. Бакаєв [24] на ряді прикладів показує, що при послідовній концентрації ресурсів на суднах («вузький фронт») сукупний ефект по групі суден виявляється вище, ніж у випадку їх паралельної обробки («широкий фронт»). До таких же висновків прийшли А.М. Обермейстер [27], Л.Д. Вітренко [28] та 
А.П. Казаков [29] у результаті дослідження питання «вузького фронту» на прикладі швидкісної обробки суден.

Надто важливі зауваження по проблематиці «вузького фронту» висловлює А.П. Дукельский [25]. Визначаючи найкращі умови обробки суден, він вказує, що завдання полягає в скороченні стоянкового часу усіх суден, які прийняті портом до обробки. У такій же постановці проблему «вузького фронту» обробки суден досліджує Чжан Хуа-юань [30].

Відмітимо, що усі дослідники завдання виконання обробки суден «вузьким фронтом» розглядали іiї в постановці, що орієнтована на досягнення ефекту тільки по флоту, без урахування інтересів портів, що не відповідає, як звісно, філософії ринкової економіки.

При відшукуванні ефективного варіанта обробки суден «вузьким фронтом» виникає завдання, яке пов'язано з встановленням оптимальної черговості завантаження-розвантаження суден. Цьому завданню приділяли увагу багато вчених, поки у 1965 році Б.А. Атлас і А.В. Постнов не показали, що це завдання не має практичного сенсу і представляє лише деякий пізнавальний інтерес [31].

Наукові результати, досягнуті на третьому етапі, зіграли істотну роль в уточненні постановок завдань про розподіл перевантажувальних ресурсів між суднами і використання ресурсів у процесі обробки суден. Дякуючи цьому, стала можливою коректна формалізація обох завдань 3 наступним їх математичним моделюванням та вирішенням з використанням точних обчислювальних методів.

Четвертий етап (1960 рік - сучасний період) - етап оптимізації і автоматизації ВОУ - відрізняє чергування періодів підвищення і зниження активності дослідників питань ВОУ. Так, на протязі 1970-х років сталося інтенсивне збагачення методології ВОУ принципами, підходами i методами наук, народжених науково-технічною революцією - кібернетики, системотехники, системного аналізу, теорії оптимізації планування і управління, економіко-математичного моделювання, календарного планування, дослідження операцій.

В цей період зусиллями великої групи авторів для завдання про перевантажувальний розподіл ресурсів між суднами розроблена ціла серія математичних моделей: лінійних і нелінійних, статичних і динамічних, детермінованих і імовірнісних, а для їх вирішення запропоновані методи математичного програмування, сіткового планування і управління, імітаційного моделювання, а також евристичні процедури.

Аналогічно на цьому етапі розвиваються дослідження про використання ресурсів при обробці суден, для рішення чого запропоновані лінійні, параметричні і мережеві моделі, що піддаються вирішенню методами лінійного програмування і календарного планування.

Завдяки зазначеним досягненням сформований і концептуально викладений в $[1 ; 2]$ ефективний підхід до дослідження процесу обробки 
суден, який базується на методології оптимального планування і управління. Усі вказані вище результати послужили основою для розгортання робіт по реалізації ВОУ в складі автоматизованої системи управління портом (АСУ «Порт»).

Відповідно до технічного завдання перша черга АCУ «Порт» проектувалася в складі двох комплексів завдань, безпосередньо пов'язаних 3 розподілом портових ресурсів між суднами та використанням ресурсів на суднах. Ці комплекси завдань отримали назви відповідно «Оперативний план роботи порту в оптимальному режимі» (ОПОРТ) і «Оптимальний технічний план-графік обробки судна» (ОТПГОС).

Центральне місце в техно-робочому проєкті комплексу завдань ОПОРТ відводилося питанням планування обробки сукупності суден на декадному інтервалі. При цьому передбачалося забезпечення безперервності планування за рахунок щодобового перескладання декадного плану 3 виключенням з нього оброблених суден і включенням суден, які прибули на протязі доби, що завершилася. Другий комплекс завдань дозволяв створювати календарні плани завантаження-розвантаження кожного 3 окремо розглядаємих суден, що фігурують в декадному плані.

В технічному завданні на проектування АСУ «Порт» також передбачався розвиток обох згаданих комплексів завдань в проекті другої черги АСУ «Порт» шляхом об'єднання їх в одному комплексі під назвою «Безперервний план-графік роботи порту в оптимальному режимі» (БПГРП).

Якщо розглядати отримані при розробці АСУ «Порт» результати в сукупності, то можна зробити висновок, що вони безумовно сприяли виявленню напрямків подальшого вдосконалення методології ВОУ. На жаль, припинення робіт з проєктування АСУ «Порт» у 1981 році обернулося втратою активності дослідників щодо питань подальшого розгляду ВОУ, в наслідок чого на протязі наступного чверть століття публікацій 3 дійсно новими результатами за вказаною проблематикою не з'явилося. Це пояснює застійний характер цього періоду, який мав у своєму активі лише дисертації І.П. Фадеєва та А.В. Степанца [6; 7], котрі однак містили наукові результати, що були одержані авторами у попередне двадцятиріччя. Крім того, з'явився ряд публікацій з актуалізацією ідей, опублікованих колись.

Ситуація застою в дослідженнях ВОУ зберігалася до початку поточного століття, коли окреслилася орієнтація дослідників на розв'язання теоретичних проблем удосконалення ВОУ у системній постановці. Найбільш чітко цей напрям віддзеркалено в статтях [32; 33], де викладено основні положення механізму реалізації ВОУ, що засновано на сполученні ідей ситуаційного, ковзного та адаптивного планування.

Разом 3 цім на протязі 2014-2017 років з серією статей виступив Ю.Ю. Крук. Він узагальнив свої наукові результати в дисертації [34], де виклав методичні основи і практичні рекомендації з підвищення ефектив- 
ності діяльності операторів портових терміналів на основі методів адаптивного управління і логістичної концепції. В ділянці ВОУ «Суднові роботи» дисертант повернувся до завдань про розподіл та використання перевантажувальних ресурсів при обробці суден за допомогою лінійних моделей, котрі є модифікаціями запропонованих у [1;2;32], аналогічних моделей.

Завершуючи обміркування сучасного етапу розвитку теорії та методів ВОУ, кратко охарактеризуємо основні положення системи автоматизованого управління портовим виробництвом під назвою «Цифрова диспетчерська» («Digital Dispatch»), що створено фірмою CYVIS і впроваджено стивідорною компанією «Новотех-Термінал» в Одеському порту, під керівництвом та при безпосередній участі Ю.І. Овсяннікова [35]. Ця система спроможна забезпечувати в режимі «оn line» реалізацію усіх загальних функцій управління у застосуванні до виробничого процесу компанії у цілому, вантажоперевалювальних машин, засобів внутрішньопортового транспорту та їх операторів. Досвід експлуатації «Цифрової диспетчерської» підтвердив іії працездатність, надійність та високу ефективність.

Створення і упровадження у портову діяльність систем автоматизованого управління, схожих на «Цифрову диспетчерську», має принципове значення, тому що воно знаменує повернення до АСУ «Порт». Звідси правомірно стверджувати, що у подальшому дослідженні питань ВОУ найбільш перспективним напрямом слід вважати створення науково бездоганного і практично ефективного математичного забезпечення ВОУ у складі економіко-математичних моделей та/або вирішальних правил, а також алгоритмів і технологій з їх адекватною і апробованою в умовах виробництва комп'ютерною реалізацією.

Висновки. Узагальнення результатів виконаних досліджень приводить до наступних констатацій:

1. На основі ретроспективного аналізу літературних джерел визначено часові межі стадій і етапів еволюції ВОУ як прикладної науки. При цьому показано, що ВОУ має донаукову і наукову стадії розвитку. Запропоновано, завершення донаукової стадії формування ВОУ пов'язувати з визначенням концепції «експлуатаційної справи в портах» (останне десятиріччя XIX століття). Запропоновано також цю подію визнавати початком наукової стадії розвитку ВОУ з виділенням у ній етапів зародження (1890-1934рр.), становлення (1928-1940рр.), створення методології (1936-1966 рр.), оптимізації і автоматизації (1960 - теперішній час).

2. Показано, що наукові основи ВОУ у частині управління процесом обробки суден у портах створено на протязі кінця 60-х-початку 70-х років XX століття $[1,2]$. Доведено, що у той час також розроблено ключові положення системної оптимізації ВОУ, а саме: 
- концепція адаптивного управління як сполучення управління програмного (планування) 3 управлінням, що слідкує (облік, контроль, аналіз) та стабілізує (регулювання);

- механізм ситуаційного планування у єдності з ковзним плануванням;

- коректні і водночас корисні для практики економіко-математичні моделі завдань розподілу перевантажувальних ресурсів між суднами та використання ресурсів при обробці суден;

- методика одночасного складання дислокаційних графіків обробки суден, планів-графіків завантаження-розвантаження окремих суден та змінно-добових планів у частині суднових робіт; «Порт».

- техно-робочі проєкти комплексів завдань першої черги АСУ

Відзначено також, що починаючи $з$ другої половини 1970-х років дослідники проблематики розвитку ВОУ працювали за формою «старі питання i завдання - поновлення їх трактовки і методів розв'язання $[33 ; 34]$.

3. Показано, що найбільш перспективним напрямом у подальшому дослідженні проблематики ВОУ є розробка сучасної версії АСУ «Порт», прототипом якої є проєкт «Цифрової диспетчерської» (CYVIS «Digital Dispatch»).

\section{ЛITEPATУРA}

1. Магамадов A.P. Оптимизачия режима обработки судов в порту при оперативном управлении [Текст]: Дис. ... канд. техн. наук: 05.22.19 / Магамадов Алексей Ризаудинович. Oдесca, 1973.

2. Магамадов A.P. Оптимизачия оперативного планирования работы порта [Текст] / A.P. Магамадов. - М.: Транспорт, 1979.

3. Тимоновъ В.Е. Объ организаціи эксплоатаціонныхъ органовъ въ портахъ [Текст] / В.Е.Тимоновъ. - С.-Петербургъ: Народная польза, 1899.

4. Поплавский Г.В. Оптимизащия оперативного регулирования обработки судов в морском порту при сменно-суточном планировании [Текст]: Дис. ... канд. техн. наук / Поплавский Герман Викторович. - Л., 1967.

5. Мартынов В.П. Оптимизаџия сокращуения стояночного времени судов в советских и иностранных портах [Текст]: Дис. ... канд. техн. наук / Мартынов Владимир Петрович. Л., 1969. 
ВІСНИК

ОДЕСЬКОГО НАЦІОНАЛЬНОГО

МОРСЬКОГО УНІВЕРСИТЕТУ № 1 (64), 2021
HERALD

OF THE ODESSA NATIONAL

MARITIME UNIVERSITY

6. Фадеев И.П. Теоретические основы оперативного управления грузовой обработкой судов в речных портах [Текст]: Дис. ... докт. техн. наук: 05.22.19 / Фадеев Иван Павлович. Горький, 1983.

7. Степанец А.В. Научные основы совершенствования управления обработкой транспортных средств в порту [Текст]: Дис ... докт. техн. наук: 05.22.19 / Степанец, Анатолий Васильевич. - Л., 1988.

8. Орлов В.К. О необходимости систематического изучения водно-эксплуатациионного дела [Текст] / В.К. Орлов // Техника и экономика путей сообщения. - 1921. - № 12-16.

9. Ещенко В.Д. НОТ на железнодорожном транспорте [Текст] / В.Д. Ещенко. - М.: Транспечать, 1924.

10. Звонков В.В. Задачи IV съезда эксплоатационников [Текст] / B.В. Звонков // Водный транспорт. - 1932. - № 11-12.

11. Ачканов Г. Объединение морского транспорта и порты [Текст] / Г. Ачканов // Водный транспорт. - 1930. - № 3.

12. Звонков В.В. Диспетчерская система на водном транспорте [Текст] / В.В.Звонков. - М.-Л.: Гострансиздат,1932.

13. Шатуновский Л.М. Оперативное планирование и диспетчеризация на морском транспорте [Текст] / Л.М. Шатуновский. - М.-Л.: Гострансиздат, 1932.

14. Мелешкин Д.Б. Диспетчерская система погрузочно-разгрузочных работ [Текст] / Д.Б. Мелешкин. - М.: ОГИЗ, 1934.

15. Руководство по низовому планированию перегрузочных работ на морском транспорте [Текст]. М.: Наркомвод, 1936.

16. Бакаєв В.Г. Эксплуатация морских портов [Текст] / В.Г. Бакаев // Труды комиссии торгового мореплавания и морского права. - Bылn.2. - М.: Внешторгиздат, 1934.

17. Киселев А.И. Диспетчерское руководство работой флота и портов в малом каботаже [Текст] / А.И. Киселев. - М.: Морской транспорт, 1940.

18. Селиванов П.А. Диспетчерская система руководства перегрузочными и рейдовыми работами порта-пристани [Текст] / П.А.Селиванов // Водный транспорт. - 1940. - № 4.

19. Звонков В.В. Теоретические основы эксплуатации транспорта [Текст] / В.В.Звонков. - Л.: АН СССР, 1949.

20. Канторович Я.Б. Вопросы эксплуатации и экономики водного транспорта [Текст] / Я.Б.Канторович. - М.: Морской транспорт, 1962.

21. Татаренко Н.С. Методика определения стояночного времени судов, расстановки кранов и составления часовых графиков [Текст] / Н.С. Татаренко // Морской флот. - 1952. - № 4-5. 
ВІСНИК

ОДЕСЬКОГО НАЦІОНАЛЬНОГО

МОРСЬКОГО УНІВЕРСИТЕТУ

№ 1 (64), 2021
HERALD

OF THE ODESSA NATIONAL

MARITIME UNIVERSITY

22. Гехтбарг Е.А. Оперативное планирование перевозок грузов на морском транспорте [Текст] / Е.А. Гехтбарг. - М.: Морской транспорт, 1962.

23. Туляков И.М. Оперативное планирование работы морского порта [Текст] / И.М. Туляков. - М.: Морской транспорт, 1962.

24. Бакаев В.Г. Организаиия грузовых работ в морских портах [Текст] / В.Г. Бакаев. - Л.-М.: Водный транспорт,1939.

25. Дукельский А.П. Механизация перегрузочных работ в морских портах [Текст] / А.П. Дукельский. - М.-Л.: Морской трансnopm, 1950.

26. Гуревич Г.Е. Организация перевозок и грузовых работ на морском транспорте [Текст] / Г.Е. Гуревич. - М.-Л.: Морской транспорт, 1952.

27. Обермейстер А. Основные положения скоростной обработки судов [Текст] / А. Обермейстер // Морской флот, 1946. № 5-6.

28. Витренко Л.Д. Руководство по организаџии скоростной обработки судов [Текст] / Л.Д. Витренко. - Л.: ЦНИИМФ, 1952.

29. Казаков А.П. Скоростные методы обработки флота [Текст] / А.П. Казаков. - М.: Речиздат, 1952.

30. Чжан Хуа-юань. Эффективность обработки судов в портах методом конщентрации перегрузочных средств [Текст] / Хуаюань Чжан. - М.: Морской транспорт, 1958.

31. Постнов А.В. Применение вычислительной техники на водном транспорте [Текст] / А.В. Постнов, Б.А. Атлас. - М.: Tранспорт, 1965.

32. Магамадов А.Р. Система оптимального внутрипортового оперативного планирования (конщепџия ОИИМФ-ОНМУ) [Текст] / А.Р. Магамадов // Вісник ОНМУ: 3б. наук. праџь. Odeca. 2005. - Bun. 17.

33. Магамадов О.P. Оптимізація оперативного управління обслуговуванням суден у портах-орендодавиях [Текст] / О.Р. Магамадов, Н.Л. Лаговська // Вісник ОНМУ: Зб. наук. nраü. - Odeca. 2015. - Bun.1(43).

34. Крук Ю.Ю. Методи адаптивного управління діяльністю оператора портового терміналу [Текст]: Дис. ... канд. техн. наук: 05.22.01 / Крук Юрій Юрійович. - Одеса. - 2017.

35. Овсянников Ю. Цифровая диспетчерская - новое слово в управлении грузовыми работами и техникой [Текст] / Ю. Овсянников // Судоходство. - 2019. - № 10. 


\section{REFERENCES}

1. Mahamadov, A.R. (1973). Optymyzatsyya rezhyma obrabotky sudov $v$ portu pry operatyvnom upravlenyy [Optimization of the mode of processing of vessels in port at operational management]. Candidate's thesis. Odessa: OIIMF [in Russian].

2. Magamadov, A.R. (1979). Optimizatsiya operativnogo planirovaniya raboty porta [Optimization of operational planning of port work]. Moscow: Transport [in Russian].

3. Timonov, V.E. (1899). Ob organizatsii eksploatatsionnykh organov $v$ portakh [On the organization of operating bodies in ports]. St. Petersburg: People's Benefit [in Russian].

4. Poplavskiy, G.V. (1967). Optimizatsiya operativnogo regulirovaniya obrabotki sudov $v$ morskom portu pri smenno - sutochnom planirovanii [Optimization of operational regulation of processing of vessels in sea port at shift - daily planning]. Candidate's thesis. Leningrad: LIIVT [in Russian].

5. Martynov, V.P. (1969). Optimizatsiya sokrashcheniya stoyanochnogo vremeni sudov $v$ sovetskikh i inostrannykh portakh [Optimization of reduction of parking time of courts in the Soviet and foreign ports]. Candidate's thesis. Leningrad: TSNIIMF [in Russian].

6. Fadeyev, I.P. (1983). Teoreticheskiye osnovy operativnogo upravleniya gruzovoy obrabotkoy sudov $v$ rechnykh portakh [Theoretical bases of operative management of cargo processing of vessels in river ports]. Doctor's thesis. Gorky: GIIVT [in Russian].

7. Stepanets, A.V. (1988). Nauchnyye osnovy sovershenstvovaniya upravleniya obrabotkoy transportnykh sredstv $v$ portu [Scientific bases of perfection of management of processing of vehicles in port]. Doctor's thesis. Leningrad: LVIMU [in Russian].

8. Orlov, V.K. (1921). O neobkhodimosti sistematicheskogo izucheniya vodno-ekspluatatsionnogo dela [On the need for a systematic study of water-operational business]. Tekhnika i ekonomika putey soobshcheniya - Railway engineering and economics, 12, 16 [in Russian].

9. Yeshchenko, V.D. (1924). NOT na zheleznodorozhnom transporte [Scientific organization of labor in railway transport]. Moscow: Transpechat, [in Russian].

10. Zvonkov, V.V. (1932). Zadachi IV s"yezda eksploatatsionnikov [Tasks of the IV congress of exploitation workers]. Vodnyy transport-Water transport, 11, 12 [in Russian]. 
11. Achkanov, G. (1930). Ob"yedineniye morskogo transporta i porty [Association of sea transport and ports]. Vodnyy transport - Water transport, №3 [in Russian].

12. Zvonkov, V.V. (1932). Dispetcherskaya sistema na vodnom transporte [Dispatching system for water transport]. Moscow Leningrad: Gostransizdat, [in Russian].

13. Shatunovskiy, L.M. (1932). Operativnoye planirovaniye $i$ dispetcherizatsiya na morskom transporte [Operational planning and dispatching at sea transport]. Moscow-Leningrad: Gostransizdat, [in Russian].

14. Meleshkin, D.B. (1934). Dispetcherskaya sistema pogruzochnorazgruzochnykh rabot [Dispatching system for loading and unloading operations]. Moscow: OGIZ, [in Russian].

15. Rukovodstvo po nizovomu planirovaniyu peregruzochnykh rabot na morskom transporte [Guidelines for Grassroots Planning of Handling Operations in Sea Transport]. (1936). Moscow: Narkomvod [in Russian].

16. Bakaêv, V.G. (1934). Eksploatatsiya morskikh portov [Exploitation of seaports]. Trudy komissii torgovogo moreplavaniya i morskogo prava - Proceedings of the Commission of Merchant Shipping and Maritime Law, 2 [in Russian].

17. Kiselev, A.I. (1940). Dispetcherskoye rukovodstvo rabotoy flota $i$ portov $v$ malom kabotazhe [Dispatching management of the fleet and ports in small cabotage]. Moscow: Morskoy transport, [in Russian].

18. Selivanov, P.A. (1940). Dispetcherskaya sistema rukovodstva peregruzochnymi i reydovymi rabotami porta-pristani [Dispatching system of management of transshipment and roadstead operations of the port-pier]. Vodnyy transport - Water transport, 4 [in Russian].

19. Zvonkov, V.V. (1949). Teoreticheskiye osnovy ekspluatatsii transporta [Theoretical foundations of transport operation]. Leningrad: AN SSSR, [in Russian].

20. Kantorovich, Y.B. (1962). Voprosy ekspluatatsii i ekonomiki vodnogo transporta [Issues of operation and economics of water transport]. Moscow: Morskoy transport - Sea transport, [in Russian].

21. Tatarenko, N.S. (1952). Metodika opredeleniya stoyanochnogo vremeni sudov, rasstanovki kranov $i$ sostavleniya chasovykh grafikov [Methodology for determining the parking time of vessels, placing cranes and drawing up hourly schedules]. Morskoy flot Marine Fleet, 4-5 [in Russian]. 
22. Gekhtbarg, Ye.A. (1962). Operativnoye planirovaniye perevozok gruzov na morskom transporte [Operational planning of cargo transportation by sea transport]. Moscow: Morskoy transport, [in Russian].

23. Tulyakov, I.M. (1962). Operativnoye planirovaniye raboty morskogo porta [Operational planning of the seaport]. Moscow: Morskoy transport, [in Russian].

24. Bakayev, V.G. (1939). Organizatsiya gruzovykh rabot v morskikh portakh [Organization of cargo operations in seaports]. Moscow Leningrad: Morskoy transport, [in Russian].

25. Dukel'skiy, A.P. (1950). Mekhanizatsiya peregruzochnykh rabot $v$ morskikh portakh [Mechanization of transshipment in seaports]. Moscow-Leningrad: Morskoy transport, [in Russian].

26. Gurevich, G.Ye. (1952). Organizatsiya perevozok $i$ gruzovykh rabot na morskom transporte [Organization of transportation and cargo operations in sea transport]. Moscow-Leningrad: Morskoy transport, [in Russian].

27. Obermeyster, A. (1946). Osnovnyye polozheniya skorostnoy obrabotki sudov [Basic provisions of high-speed handling of ships]. Morskoy flot - Marine Fleet, 5-6 [in Russian].

28. Vetrenko L.D. (1952). Rukovodstvo po organizatsii skorostnoy obrabotki sudov [Guidelines for the organization of high-speed handling of ships]. Leningrad: TSNIIMF, [in Russian].

29. Kazakov, A.P. (1952). Skorostnyye metody obrabotki flota [Highspeed methods of fleet processing]. Moscow: Rechizdat, [in Russian].

30. Chzhan Khua-yuan (1958). Effektivnost obrabotki sudov v portakh metodom kontsentratsii peregruzochnykh sredstv [Efficiency of handling ships in ports by the method of concentration of transshipment facilities]. Moscow: Morskoy transport, [in Russian].

31. Postnov, A.V. (1965). Primeneniye vychislitel'noy tekhniki na vodnom transporte [The use of computer technology in water transport]. Moscow: Transport, [in Russian].

32. Mahamadov, O.R. (2005). Systema optymalnoho vnutryportovoho operatyvnoho planyrovanyya (kontseptsyya OYYMF-ONMU) [System of optimal intraport operational planning (concept OIIMF - ONMU)]. Visnyk ONMU. - Bulletin of ONMU, Vyp.17 [in Russian].

33. Mahamadov, O.R. \& Lahovska, N.L. (2015). Optymizatsiya operatyvnoho upravlinnya obsluhovuvannyam suden u portakh orendodavtsyakh [Optimization of operational management of ship services in ports - lessors]. Visnyk ONMU. - Bulletin of ONMU, 1 (43) [in Russian]. 
ВІСНИК

ОДЕСЬКОГО НАЦІОНАЛЬНОГО

МОРСЬКОГО УНІВЕРСИТЕТУ

№ 1 (64), 2021
HERALD

OF THE ODESSA NATIONAL

MARITIME UNIVERSITY № 1 (64), 2021

34. Kruk, Y.Y. (2017). Metody adaptyvnoho upravlinnya diyal'nistyu operatora portovoho terminalu [Methods of adaptive management of the port terminal operator]. Candidate's thesis. Odessa: ONMU [in Ukrainian].

35. Ovsyannikov, Y. (2019). Tsifrovaya dispetcherskaya - novoye slovo $v$ upravlenii gruzovymi rabotami $i$ tekhnikoy [Digital dispatching - a new word in the management of cargo operations and equipment]. Sudokhodstvo - Shipping, 10 [in Russian].

Стаття надійшла до редакиії 25.03.2021

Посилання на статтю: Кириллова О.В., Магамадов О.Р., Шурін Б.В. Зародження і розвиток внутрішньопортового оперативного управління // Вісник Одеського національного морського університету: Зб. наук. праць, 2021. № 1 (64). C. 82-98. DOI 10.47049/ 2226-1893-2021-1-82-98.

Article received 25.03.2021

Reference a JournalArtic: Kirillova E.V., Magamadov A.R., Shoorin B.V. The origin and development of intraport operational management // Herald of the Odessa national maritime university. 2021. 1(64), 82-98. DOI 10.47049/ 2226-1893-2021-1-82-98. 